\title{
Fictional Menageries: Writing Animals in the Early Twenty-First Century. A Review of Timothy C. Baker, Writing Animals: Language, Suffering, and Animality in Twenty-First-Century Fiction. Cham: Palgrave Macmillan, 2019, 242 pages, ISBN 978-3-030-03879-3, hardcover $86 \$$
}

\author{
Antonis Balasopoulos
}

\section{University of Cyprus}

E-mail: balaso@ucy.ac.cy

In 'On the Animal Turn', Harriet Ritvo notes that though 'learned attention to animals is far from new', stretching indeed as far back as Aristotle's Historia Animalium, 'nevertheless, during the last several decades, animals have emerged as a more frequent focus on scholarship in the humanities and social sciences, as quantified in published books and articles, conference presentations, new societies, and new journals. ${ }^{1}$ Before delving into Timothy C. Baker's Writing Animals, itself part of one of a scholarly series to have emerged in this budding field (Palgrave Studies in Animals and Literature), it is useful to note a few things about the circumstances attending the field's rise.

As its name clearly suggests, literary animal studies is a subset within the array of subfields within so-called 'critical animal studies', which also include ecology, philosophy, ethics, history, cognition and language studies, but also, and equally importantly, social justice and activist movements, from ones focused on preservation of habitats, the humane treatment of animals and the ban on industrial and medical exploitation and cruelty to positive animal rights in freedom and dignity, to vegetarianism and veganism. Institutionally, as we learn from the accounts of Nik Taylor and Richard Twine, as well as Anthony J. Nocella II et al., critical animal studies grew out of nineteenth-century interventions like Henry Salt's Animals' Rights Considered in Relation to Moral Progress of 1894 and the post WW2 confluence between animal rights and other social justice movements as reflected in Peter Singer's foundational Animal Liberation of 1975, until they led to the foundation of the Center on Animal Liberation Affairs in 2001 and the Institute for Critical Animal Studies in 2007. The affiliated Journal for Critical Animal Studies was re-launched in the same year as a follow-up to its previous incarnation, the Animal Liberation Philosophy and Policy Journal, founded in $2003 .^{2}$

\footnotetext{
${ }^{1}$ Harriet Ritvo, 'On the Animal Turn', Daedalus: Journal of the American Academy of Arts and Sciences 136:4 (Fall 2007): 118-19.

${ }^{2}$ Nik Taylor and Richard Twine, 'Locating the "Critical" in Critical Animal Studies', in The Rise of Critical Animal Studies: From the Margins to the Centre, ed. Nik Taylor and Richard Twine (London and New York: Routledge, 2014), 1-15; and Anthony J. Nocella II, John Sorenson, Kim Socha and Atsuko Matsuoka, 'Introduction. The Emergence of Critical Animal Studies: The Rise of Intersectional Animal
} 
The cross-pollination between critical animal studies and literary criticism has therefore engendered a certain set of complications in literary animal studies. One way of putting the issue is in terms of the potential or actual tension between the strongly normative tendencies inherent in the more activist and interventionist strands within critical animal studies and the more descriptive and analytical tasks specific to literary criticism; another, and indirectly related one, concerns the difference addressed by Roland Borgards, namely that between literary animals - animals made of words - and real animals. As Borgards succinctly puts it, 'literary wolves cannot bite us and in turn we as readers cannot kill them. ${ }^{3}$ It is highly problematic, in other words, to treat literary texts as the same kinds of venues for ethical and activist intervention as it is to treat the food industry, though, and at the same time, it is equally problematic to posit a categorical distinction between literary and real animals, since the former are informed by the latter and in some cases may play a role in shaping attitudes toward the latter: witness the case of Anna Sewell's vastly popular Black Beauty (1877), for instance, and its impact on the abolition of the bearing-rein as cruel for horses ${ }^{4}$; or the impact of E.B. White's Charlotte's Web (1952) on attitudes toward meat-eating. In fact, some animal literature has a long history of adopting a normative ethical stance and serving concrete goals in the interests of a measure of reform in the treatment of animals (usually domesticated ones).

On the other hand, and as the first chapter of Baker's book makes clear, literary animal studies have equally been informed by a philosophical and theoretical focus that is not always either normative or activist in orientation and that is not even primarily concerned with animals but rather with a critique of what we know as 'humanism' and its underlying assumptions. As Baker notes, for instance, Martin Heidegger's philosophy has persisted in denying animals participation in the privileged realm of the thinking of Being - since, for Heidegger, that realm is fundamentally predicated on language - but it has nonetheless had a great impact on critical animal studies. In fact, Baker will defend Heidegger from criticism for categorically privileging the human animal by noting that 'Heidegger is not establishing a clear binary' in his claims, 'nor attempting to define the animal in relation to the human' (9). In this case, Heidegger's deconstruction of humanism - his claim that '[e]very humanism is either grounded in a metaphysics or made to be the ground of one', however much metaphysics paradoxically 'thinks of man on the basis of animalitas' ${ }^{5}$ - has proven as foundational as a more affirmative agenda in favour of animal rights.

Since his focus is the analysis of the uses of animal figures in a broad array of twenty-first century fictions, Baker does not address the nature of the complex intersections between the rise of critical animal studies and the critique of humanism we find in Heidegger's 'Letter on Humanism' in 1946-1947, shortly after the end of WW2.

Liberation', in Defining Critical Animal Studies: An Intersectional Social Justice Approach for Liberation, ed. Anthony J. Nocella et al. (New York: Peter Lang, 2014), xix-xxxvi.

${ }^{3}$ Roland Borgards, 'Introduction: Cultural and Literary Animal Studies', Journal of Literary Theory 9:2 (2015): 155-60.

${ }^{4}$ See Robert Dingley, 'A Horse of a Different Color: "Black Beauty” and the Pressures of Indebtedness', Victorian Literature and Culture 25:2 (1997): 241-51. The ethical and terminological connection between Sewell's book and abolitionist literature is not accidental. See Peter Stoneley, 'Sentimental Emasculations: Uncle Tom's Cabin and Black Beauty', Nineteenth-Century Literature 54:1 (1999): 53-72. ${ }^{5}$ Martin Heidegger, 'Letter on Humanism', in Basic Writings, ed., trans. and intr. David Farrell Krell (New York: Harper \& Row, 1977), 202, 204. 
Heidegger's fascist sympathies notwithstanding, his scepticism toward humanism resonated with an intelligentsia that felt compelled to confront the effectively unthinkable realities of mass human extinction, including the Holocaust and the use of the atom bomb, which had claimed center stage in the post-war period. Along with the industrialization of animal slaughter and the sharp rise in the use of animals in painful and often lethal medical experiments, the post-WW2 conjuncture of a deep crisis within 'humanism' seems to me to of vital significance for understanding the impetus behind the decentrings contemporary literature undertakes through its engagement with animals - as vital as the contemporary prominence of severe ecological crisis in the era of the so-called "Anthropocene" (or, in other and more explicitly anti-capitalist versions, the 'Capitalocene'). These could be understood as the most recently established pillars of both critical animal studies generally and the study of literary animals specifically. ${ }^{7}$ Writing on Kafka in his 1955 Prisms, Theodor W. Adorno noted that the Prague author 'tears down the soothing façade to which a repressive reason increasingly conforms. [...] [he] drives through to the bare material existence that emerges in the subjective sphere through the total collapse of a submissive consciousness.' 'The flight through man and beyond into the non-human', Adorno concluded, 'is Kafka's epic course.' ${ }^{8}$ The zone where the negation of humanist self-complacency embodied in the 'flight into the nonhuman' can come into play with the specifically literary and aesthetic challenges involved in what the Formalists termed 'estrangement' ${ }^{9}$ - the reimagining of what familiarity and habit has rendered opaque and unreflective - this seems to me to constitute the unhomely zone wherein literary animal studies makes its home.

In his first chapter - and the one dedicated to charting the basic theoretical coordinates of his forays into twenty-first century literature - Baker initially deals with the centrality of language in the human-animal distinction, tracing the limits that the privileging of language poses for any attempt to fundamentally challenge the binary opposition of the two. In the words of Wendy Doniger, whom he quotes, '[s]ince language is the lens through which we view the world, it is easy to understand how we failed to see, through these lenses, that our lenses - our categories, our words for humans and for animals - were badly skewed' (13). The abiding anthropocentrism of every approach that, along with Heidegger, privileges language as the fundamental realm for the exploration of Being, leads Baker into the second of the categories listed in his subtitle: suffering. The foundation is Derrida's re-appropriation of Bentham's remark on the limits of penal law in The Animal That Therefore I Am: 'Bentham, as is well known, proposed changing the very form of the question regarding the animal that dominated discourse within the tradition. [...] Thus the question will not be to know whether animals [...] can speak or reason thanks to that capacity or that attribute of the

\footnotetext{
6 The term was coined by Paul J. Crutzen and Eugene F. Stoermer in 2000. See their 'The "Anthropocene", IGBP Newsletter 41 (May 2000): 17-18.

${ }^{7}$ See Darko Suvin, 'Utopia or Bust: Capitalocene, Method, Anti-Utopia', Utopian Studies 32:1 (2021): 135, esp. 1-13. The term, as Suvin notes, was coined by. Jason W. Moore in 2016; on the relation between critical animal studies and anti-capitalism, see Taylor and Twine, "Locating the "Critical", 9-11 and chapters 7-9 in their volume. It is noteworthy that Baker's study pays virtually no attention to this dimension.

${ }^{8}$ Theodor W. Adorno, 'Notes on Kafka', in Prisms, trans. Samuel and Shierry Weber (Cambridge, MA: MIT Press, 1983), 251-2.

${ }^{9}$ See Victor Shklovsky, 'Art, as Device’, trans. Alexandra Berlina, Poetics Today 36:3 (September 2015): $151-74$.
} 
logos [...] The first and decisive question would rather be to know whether animals can suffer'. ${ }^{10}$ As passive capacities, ${ }^{11}$ suffering, vulnerability, grief and mourning link human and animal not predominantly in terms of affinity but rather in terms of an encounter, in which both their shared non-power and their differences can be articulated (17). Ultimately, the shared experience of passivity and nonpower leads writers to engagement with the negative universality of the experience of death - what Derrida calls 'the finitude we share with animals'. ${ }^{12}$

The themes of language, representation and representability, as well as these of suffering and death, are then the focal points of three of the five remaining chapters of Baker's study: in the second chapter, the author focuses on four twenty-first century novels which intertextually address these questions in Franz Kafka's foundational (especially for literary animal studies) 'A Report to an Academy' (1917): J.M. Coetzee's Elizabeth Costello (2003), Karen Joy Fowler's We Are All Completely Beside Ourselves (2013), Ceridwen Dovey's Only the Animals (2014) and Yoko Tawada's Memoirs of a Polar Bear (2014). Chapters four and five dwell on animal and human suffering and death in Evie Wyld's All the Birds, Singing (2013), Yannick Murphy's The Call (2011), Keith Ridgway's Animals (2003), Sara Baume's A Line Made by Walking (2017), Lydia Millet's How the Dead Dream (2008), Alexis Wright's The Swan Book (2013), Jeff VanderMeer's Southern Reach trilogy (2014), and Adam Roberts' Bête (2014). In the remaining two chapters, Baker focuses on themes of human-animal and animal-human transformation, with a special emphasis on the gendered figure of the fox (chapter 2) and on the visual use of 'animal language' in children's and young adult fiction (chapter 6). Primary focus in these two chapters is on Sarah Hall's Mrs Fox (2014) and its antecedent text, David Garnett's Lady into Fox (1922), Kij Johnson's The Fox Woman (2000), Emma Geen's The Many Selves of Katherine North (2016), Paula Cocozza's How to Be Human (2017), Aminatta Forna's Happiness (2018); and on Kate DiCamillo's Flora \& Ulysses, Claire Barker's Knitbone Pepper series (2013-2015), Patrick Ness's The Knife of Never Letting Go (2008) and Ursula Vernon's Hamster Princess series (2015-2018). As is readily apparent, this is a very large corpus for a single study (indeed, since Baker also alludes to a number of other twenty-first century novels and stories as well as a few important antecedents, his list of primary texts extends to a whopping eighty-five). The result is a tendency to privilege comprehensiveness over in-depth engagement and to inundate the novice in the field with a little too much by way of names and titles, though, on the flipside, the book has the advantage of being a very useful resource for further research into a still emergent and largely unexplored field.

Chapter 1 sets out from Descartes' well-known exclusion of animals not only from language and reason but, relatedly, from the experience of suffering, since 'suffering [...] is reserved for humans, and is implicitly tied to language, or the ability to communicate' pain (41). Baker initially examines the paradoxical implications of this predication of suffering on the possession of human language in Franz Kafka's 'A

\footnotetext{
${ }^{10}$ Jacques Derrida, The Animal That Therefore I Am, ed. Marie-Louise Mallet, trans. David Wills (New York: Fordham University Press, 2008), 27.

${ }^{11}$ See Derrida, The Animal That Therefore I Am, 28: "“Can they suffer?" amounts to asking "Can they not be able?" And what is this inability? [...] What is this nonpower? [...] What rights should be accorded to it?'

${ }^{12}$ Derrida, The Animal that Therefore I Am, 28.
} 
Report to an Academy', since Red Peter, Kafka's imagined ape, can only represent his suffering as an ape in captivity in human terms and in human language, therefore fundamentally misrepresenting it (Writing Animals 43). Delving into the complexities and ambiguities involved in Coetzee's use of Kafka as well as in the generic nature of Elizabeth Costello (part fiction, part non-fiction, partly a vehicle for the author's own views and partly one for ironic distancing from an elderly woman's disenchantment with humanity and with herself), Baker concludes that 'the novel, taken as a whole, implies that any pronouncement on nonhuman animals by humans will be incomplete, and possibly misguided' (51). Literature can provide us with access to the nature of suffering, but only on the condition that this consciousness is mediated, including its mediations by previous literary texts (51-52). In Fowler's We Are All Beside Ourselves, the ambiguous nature of language as a vehicle for both disclosure and deception renders it an imprecise and therefore unreliable measure of the difference between humans and animals. Indeed, as Baker shows by way of Benjamin Hale's The Evolution of Bruno Littlemore (2011), there is a sense in which the human possession of language marks a deficit, or a 'bad discontinuity' (54) in relation to animals, since it reveals the 'inner death' of the 'sense of perpetual amazement at the ever-renewed world' that marks our acute nostalgia for a happiness and fulfilment now forever lost to us (Hale, in Writing Animals 59). Perhaps, as Dovey's Only the Animals suggests in regards to Kafka's urtext, "what separates human and nonhuman animals is not speech or reason [...] but the human ability to take pleasure in pain' (62); perhaps too, as Tawada's Memoirs of a Polar Bear intuits, Kafka's story, along with the rest of his fiction on animals, does not offer any insight on the relationship of animal and human but rather an exploration of a forgetting that accompanies the unstable ontological state of transformation, from animal to human and from human to animal (65).

Transformation constitutes the centre of the second chapter, wherein Baker engages with the idea that 'both bodies and stories are open to the world, and to a constant process of transformation and metamorphosis' (75-6). The privileged animal avatar here is the fox, 'neither wholly human nor nonhuman' but rather 'an index of both similarity and difference' (78). Unlike traditional narratives of metamorphosis, which often 'favour a return to order' in Bruce Clarke's formulation, Baker's examples rather attest to a refusal of 'renaturalization" (80)'. In them, the relationship between human and animal is predicated on a shared experience of the messy realities of change. Instead of making metamorphosis a vehicle for mutual interspecies understanding, then, Hall's Mrs Fox revises David Garnett's earlier Lady into Fox to suggest that the 'absence of understanding' is at 'the centre of all relations, human and nonhuman' (88). Kij Johnson's The Fox Woman, on the other hand, also revisits an earlier tale, the Japanese 'The Fox-Wife of Bitchū', to imagine a hybrid narrative subject that is 'neither simply fox nor human but both and neither'; an instance of what Braidotti views as 'nomadic subjectivity', embodying and defying both fox and human appearance, the relation to patriarchal modes of authority and the import of textual formation (90). In Geen's The Many Selves of Katherine North, the theme of human-fox metamorphosis acquires sci-fi overtones, given the fact that it is premised on future technology, and thus recasts the question of human-animal relationships through the lens of a fascination with prosthesis and with the idea of bodies as 'infinitely replaceable' (94). Finally, Cocozza's How to Be Human explores the theme of interspecies desire as a possibility whose potential for estrangement makes it compelling for literature, even as it therefore also 'embraces the anthropocentric perspectives' the previous human-fox narratives 
sought to avoid (97); while Forna's complexly structured Happiness entangles narrative strands concerning urban fox populations and post-traumatic stress disorder in order to explore the shared interspecies capacity to suffer as the basis for a 'more global, more inclusive approach to living' (101).

The topic of trauma allows Baker to segue into the third chapter, which frames its subject in terms of Judith Butler's influential intervention into the question of 'grievable lives': ${ }^{13}$ the possibility of mourning has traditionally marked the human, while its absence signals the bare life of what has been dehumanized and divested of life-value. Not accidentally, 'it is only through humanisation, in terms of naming and attention to individual biography, that the animal can be grieved' (Writing Animals, 111). Still, to the extent that grief, in overwhelming the subject, 'undoes the individual who is grieving', grief for animal death can exceed the limits of humanizing the other and lead into a 'recognition of shared vulnerability and finitude' (111-12). It may also recast death not as an end but as a moment in the endless becoming and transformation of matter, thus leading into a broader questioning of the 'borders between life and death, between human and animal, and between self and other' (114). ${ }^{14}$ In Wylde's All the Birds, Singing, Baker notes, the death of animals has become endemic, constituting a 'form of patriarchal control that is visited both on nonhuman animals and human women' (122). In Murphy's The Call, on the other hand, the casting of the protagonist, David, as a veterinarian, makes animal death more quotidian, until his son is injured in a hunting accident, making David 'reconsider the relation between violence done to human and nonhuman animals' (122). Both novels are marked by a 'lack of clear resolutions' that would allow for a reinstatement of fixed demarcations, thus gesturing to the 'degree in which life, as zoe, is shared', equally characterised by vulnerability and exposure to death or decreation in animals and humans. Ridgway's Animals and Baume's A Line Made by Walking explore these themes by focusing on smaller - and thus less frequently 'relatable' - animals: a mouse in the case of the former, various small animals in that of the latter. Aesthetic self-reflexiveness is fundamental to both of these explorations: while in Ridgway's novel the death of a mouse reveals, in its sheer incomprehensible facticity, that 'the order of things is itself partial' (128), in Baume's text aesthetic mediation, in the form of photography, unveils a world of 'shared vulnerability', where, in the protagonist's words, 'only art and sadness last forever' (135).

For Baker, animal death motivates the twenty-first century novel into new forms of estrangement, geared at comprehending, at once, the shared experience of finitude and the limits of all 'self-understanding' (137). In the next and fifth chapter, the confrontation, by representation, of the largely unrepresentable, encounters the pressures placed upon literary narrative by the advent of the Anthropocene. In The Great Derangement, Amitav Ghosh remarks that there is an essential incompatibility between the assumptions of bourgeois ordinariness in novelistic realism and the kinds

\footnotetext{
13 See Judith Butler's Precarious Life: The Powers of Mourning and Violence (London: Verso, 2004); and her Frames of War: When is Life Grievable? (London: Verso, 2009).

${ }^{14}$ Baker cites Simone Weil and Rosi Braidotti in this connection, but the tradition of rethinking death in terms of transformation and becoming surely extends as far back as Lucretius' De Rerum Natura, itself a poetic revision of Epicureanism and Epicurus' atomic philosophy: 'Thus things that seem to perish utterly, do not. See how/ Nature refashions one thing from another, and won't allow/ A birth unless it's midwived by another's death'. Lucretius, The Nature of Things, trans. A. E. Stallings (London: Penguin, 2007), 11 .
} 
of improbabilities that climate change has made reality: '[i]n the era of global warming, nothing is really far away; there is no place where the orderly expectations of bourgeois life hold unchallenged sway.' Indications of climate change, he adds, 'are not merely strange in the sense of being unknown or alien; their uncanniness lies precisely in the fact that in these encounters we recognize something we had turned away from: that is to say, the presence and proximity of non-human interlocutors. ${ }^{, 15}$ Relatedly, for Baker, the Anthropocene 'can be posited as an attempt to think not only past the human, but past human ways of knowing' (148). This then is the framework within which Millet's How the Dead Dream, Wright's The Swan Book, VanderMeer's Southern Reach trilogy (Acceptance, Annihilation and Authority) and Robert's Bête operate: Millet's novel ultimately dramatizes the failure to 'imagine the Anthropocene' (157), the globe itself becoming an inadequate signifier for reality (158); while Wright's text, set in a near and dystopian future, and contrasting Western and Indigenous perspectives only to end in aporia, 'suggests that climate change is simultaneously only approachable on global and individual levels, rather than purely cultural or community-based ones' (161). Deploying the generic possibilities of Weird fiction, VanderMeer's Southern Reach Trilogy explores a decentred world of unstable ontological states, challenging 'traditional species and cultural divisions' between humans, aliens, animals and ghosts (164); while Roberts's fiction delves into the "“absurd and contradictory" world' that would be entailed by 'animal consciousness and language' (172) in order to speculate on an economy of generalized sacrifice, where human and non-human animals are 'all killed and ingested', and where sacrifice 'becomes a way to think about the always shared, always individual experience of love' (175).

The final chapter is in some ways the most captivating one, since its subject matter and field of research are combined in a manner one rarely encounters in scholarship: the material uses of typeface and page arrangements to represent, in textually embodied form, non-human perspectives within children's and young adult fiction, wherein the sense of the transformability of the world makes possible a certain form of pedagogical playfulness that offsets the mostly grim atmosphere of the climate change fiction of the previous chapter, as well as of the dystopic preoccupations with 'bare' and killable life that have marked a great deal of post-humanist fiction and criticism in the last decades. In Ness' fiction, Baker accordingly notes that the combination of 'different typographies and voices opens a world by refusing the authority of the standard written text' (190); while the invention of what Ness calls 'the Noise' - the sound of life in all its anarchic and unrepresentable complexity, a concept Ness seems to owe to his reading of a passage from George Eliot's Middlemarch interlaces the experience of all beings, human and nonhuman. Barker's Knitbone Pepper series makes spectrality into an equivalent zone of shared experience, suggesting, as Baker notes, that the pictorial world of the illustrated text can help overcome the 'binary between humans and animals, and living and dead' (199). Finally, DiCamillo's Flora \& Ulysses - in Baker's view, 'the most hopeful' and 'certainly the funniest' of the texts under consideration - suggests that a narrative blending human and nonhuman voices and types of text 'provides one of the best ways to think about the relation between different species, as well as the centrality of suffering and love to any shared world' (203). Ultimately, Baker concludes, paying 'attention to animals requires

\footnotetext{
15 Amitav Ghosh, The Great Derangement: Climate Change and the Unthinkable (Chicago: The University of Chicago Press, 2016), 26, 30.
} 
realizing that human language is not sufficient to encompass the world, and that human understanding does not lead to a privileged, sovereign state of being' (204). For 'neither traditional species hierarchies nor traditional narrative forms are sufficient to understand, or survive in, the world, and yet remain essential ways to conceptualize the world' (205).

The very large number of primary texts examined in Baker's book makes it something of a survey, with the pluses and minuses of that genre of study: on the one hand, it is one of the most comprehensive studies of early twenty-first century animal fiction one is likely to find; on the other, it tends to be less driven by strong theoretical argument and more by case-by-case observation, which, given the heterogeneity and philosophical divergences of the primary texts it engages with, can prove rather frustrating to the impulse to draw general conclusions. The heterogeneity of the strands of the theoretical framework itself (the differences, for example, between Simone Weil's and Rosi Braidotti's accounts of death, or between Heidegger's and Derrida's or Agamben's views of the stakes involved in thinking animal life) ${ }^{16}$ prevents any allround synthesis of directions in argumentation - though I suspect that such synthesis is not viewed as a sustainable desideratum by the author, who instead opts for a more inclusive presentation of diverging theoretical and hermeneutic possibilities. Finally, and as I mentioned in the introduction to this essay, there are tensions between the descriptive and analytical apparatus of literary criticism, on the one hand, and the more normative and ethically charged frameworks of activist thought on the other. These are particularly evident in the author's frequent and apparently critical references to 'anthropocentrism' in the texts involved - a charge he is elsewhere compelled to admit is rather unavoidable when one deals with material premised on human writing, human language and criteria of intelligibility toward a human audience. The ethical injunction to valorise a writing that allows us to become somehow 'better' in our understanding and treatment of animals (as inherited from the social justice-oriented and activist legacy of critical animal studies) does not always sit comfortably with literature's scepticism toward ethical certainties, nor is it always adequately cognizant of the impulse to 'make strange' as an imperative that makes sense in the ethical horizon immanent to literature. One of course continues to look to literary texts in search of pedagogical instruments able to reveal 'new ways of being in the world' (205); but there are never guarantees that aesthetic pleasure with what is new or unusual (or, indeed, uncanny) will also bring to bear a measurable impact on our extra-fictional, 'real world' attitudes toward our experience.

\section{Bibliography}

1. Adorno, Theodor W. 'Notes on Kafka'. In Prisms. Translated by Samuel and Shierry Weber. Cambridge, MA: MIT Press, 1983.

2. Borgards, Roland. 'Introduction: Cultural and Literary Animal Studies'. Journal of Literary Theory 9:2 (2015): 155-60.

3. Butler, Judith. Frames of War: When is Life Grievable? London: Verso, 2009.

${ }^{16}$ For useful introductions to the basic theoretical pillars of animal studies from a philosophical standpoint, see Matthew Calarco, Zoographies: The Question of the Animal from Heidegger to Derrida (New York: Columbia University Press, 2008); and Animal Philosophy: Essential Readings in Continental Thought, ed. Matthew Calarco and Peter Atterton (London: Continuum, 2004). 
4. Butler, Judith. Precarious Life: The Powers of Mourning and Violence. London: Verso, 2004.

5. Calarco, Matthew and Peter Atterton. Editors. Animal Philosophy: Essential Readings in Continental Thought. London: Continuum, 2004.

6. Calarco, Matthew. Zoographies: The Question of the Animal from Heidegger to Derrida. New York: Columbia University Press, 2008.

7. Crutzen, Paul J. and Eugene F. Stoermer. 'The "Anthropocene"'. IGBP Newsletter 41 (May 2000): 17-18.

8. Derrida, Jacques. The Animal That Therefore I Am. Edited by Marie-Louise Mallet. Translated by David Wills. New York: Fordham University Press, 2008.

9. Dingley, Robert. "A Horse of a Different Color: "Black Beauty" and the Pressures of Indebtedness'. Victorian Literature and Culture 25:2 (1997): 241-51.

10.Ghosh, Amitav. The Great Derangement: Climate Change and the Unthinkable. Chicago: The University of Chicago Press, 2016.

11.Heidegger, Martin. 'Letter on Humanism'. In Basic Writings. Edited, Translated and Introduced by David Farrell Krell. New York: Harper \& Row, 1977.

12.Lucretius. The Nature of Things. Translated by A. E. Stallings. London: Penguin, 2007.

13.Nocella, Anthony J., John Sorenson, Kim Socha and Atsuko Matsuoka. 'Introduction. The Emergence of Critical Animal Studies: The Rise of Intersectional Animal Liberation'. In Defining Critical Animal Studies: An Intersectional Social Justice Approach for Liberation. Edited by Anthony J. Nocella et al. New York: Peter Lang, 2014. xix-xxxvi.

14.Ritvo, Harriet. 'On the Animal Turn'. Daedalus: Journal of the American Academy of Arts and Sciences 136: 4 (Fall 2007): 118-22.

15.Shklovsky, Victor. 'Art, as Device'. Translated by Alexandra Berlina. Poetics Today 36:3 (September 2015): 151-74.

16. Stoneley, Peter. 'Sentimental Emasculations: Uncle Tom's Cabin and Black Beauty'. Nineteenth-Century Literature 54:1 (1999): 53-72.

17.Suvin, Darko. 'Utopia or Bust: Capitalocene, Method, Anti-Utopia'. Utopian Studies 32:1 (2021): 1-35.

18.Taylor, Nik and Richard Twine. 'Locating the "Critical" in Critical Animal Studies'. In The Rise of Critical Animal Studies: From the Margins to the Centre. Edited by Nik Taylor and Richard Twine. London and New York: Routledge, 2014. 1-15. 
